\section{U.S.-JAPAN \\ COOPERATION \\ INCREASING}

Marketing, R\&D, and equity arrangements between M Japanese firms and those headquartered in Europe and North America have been an integral part of biotechnology almost from its inception. For example, Genentech (South San Francisco, CA) is partially owned by a Japanese investor group, is doing contract or joint research with Japanese companies on tissue plasminogen activator, gamma interferon, and human serum albumin, and maintains an array of marketing agreements with several Japanese companies. Most industry experts foresee this kind of international mutualism continuing, but it is undergoing subtle changes as Japanese companies increase their technological expertise, and as biotech specialty concerns mature.

"If there is any kind of trend in biotechnology joint ventures, I'm quite sure they will increase rather than decrease," declares Hiro Sato, of the research department at the Japan Trade Center (New York, NY). He says recent discussions on industrial cooperation between the U.S. and Japan, combined with increasing interest of large Japanese trading companies-such as Mitsui, Mitsubishi, and Marubeni-in commissioning $\mathrm{R} \& \mathrm{D}$, will be sufficient to inspire new agreements.

Other observers are not so sure that new biotech agreements will continue to proliferate. They note that many of Japan's industrial giants already have deals in place with top genetic engineering firms that could support new projects. This could mean that not all the new U.S. and European start-ups will be able to garner lucrative Japanese agreements.

Alan G. Walton, president of University Genetics (Norwalk, CT), points out, however, that while most Japanese pharmaceutical companies are now pursuing biotechnology actively, companies involved in organic and agricultural chemicals have not committed themselves heavily yet. He expects, therefore, to see many co-ventures in the near future. A technology licenser, Walton views the Japanese as particularly interested in technology that they can translate into marketable products within two years, including biological pesticides and metabolites derived from cell culture.

Katsuyoshi Yamashita, head of technical development of Mitsui \& Company U.S.A. (New York, NY), says he expects that more biotechnology cross-licensing and joint ventures will take place. As Japan develops its expertise it will be able to offer more to an agreement than just funding and a marketing network. "Give-and-take may become more popular," he claims. Don Iguchi, manager of Mitsubishi International Corp.'s American project coordination center, agrees, reporting that while Japan still imports more technology than it exports, this trade balance is equalizing. "I think the U.S. companies see Japanese companies more as qualified partners, rather than licensees," he reports. He claims that Japanese mass production and fermentation know-how could become an increasingly valuable asset to U.S. firms as the commer- cialization of genetic engineering gears up. He also warns that world-wide markets for biotechnology products may not be as large as some people predict, so Japanese marketing rights could prove important. Japan represents the second largest drug market in the world, and its residents use more pharmaceuticals per capita than those of any other country.

Japan, through MITI's ministrations and the actions of the country's pharmaceutical companies, is making a concerted effort to import and develop biotechnical expertise. "Once they catch up, I don't see any any need for these R\&D arrangements," says Robert J. Erickson, technical director of Integrated Genetics (Framingham, MA). His company reached an agreement last fall with Fujirebio (Tokyo) for the Japanese manufacturing and distribution rights to Integrated's hepatitis B diagnostic test. As part of the arrangement, Fujirebio received certain rights to the DNA probe technology used in the test. Erickson reports that C. Itoh \& Co. (Osaka), which recently purchased equity in Integrated, now serves as the company's representative in Japan. In the future, he says, he foresees C. Itoh's role as more two-sided: it also will represent Japanese products and technologies abroad.

Changes in Japanese law regarding the interests of foreign companies in Japan have allowed foreign firms to maintain fully-owned subsidiaries there only since 1975 . Although Genentech maintains a Japanese subsidiary, Genentech Ltd, this rule change has affected the large pharmaceutical houses most. Merck \& Company (Rahway, $\mathrm{NJ}$ ), for example, recently bought a controlling percentage of the Banyu Pharmaceutical Company (Tokyo) for more than $\$ 300$ million, and it paid about $\$ 10$ million to bring its equity interest in Torii Yakuhin K.K. (Tokyo) to more than 50 percent. According to a U.S. government expert, this kind of takeover could be repeated by other U.S. multinationals, and maybe even by one or more of the largest biotech specialty companies. This implied threat, the expert reasons, could influence Japanese companies to give up more when making agreements with U.S. firms.

At the same time U.S. concerns are making inroads into Japan, the reverse is also occurring. Recently, Otsuka Pharmaceutical Co. (Osaka) announced a \$5 million genetic engineering research laboratory at the Shady Grove Life Sciences Center (Montgomery County, MD), and Ajinomoto (Tokyo) completed an amino acid production plant in Raleigh, NC.

While corporate interaction is increasing in both directions, many more of Japan's researchers study abroad than outsiders do in Japan. As a result, these Japanese researchers return with some western attitudes. One such scientist, Masa Misawa, spent two years as a postdoctoral student in Ottawa, Canada, in the middle of a 20 year career at Kyowa Hakko Kogyo (Tokyo) that climaxed with a position as director of research of its yeast group. Last winter, however, he left to become manager of fermentation microbiology at Allelix (Mississauga, Ontario). He points out that more Japanese researchers are jumping between Japanese companies than ever before, and those who speak English are now looking toward other countries as well. If this trend develops, it could silence American critics who argue that there are few tangible returns for allowing many Japanese researchers to study in the U.S.

Strategic Technologies International and Japan Pacific Associates assisted in the preparation of the feature article appearing on pages $307-321$. 